\title{
Tales of the Land: British Geography and Kandyan Resistance in Sri Lanka, c. $I 803-I 850^{1}$
}

\author{
SUJIT SIVASUNDARAM
}

Gonville and Caius College, Cambridge

\begin{abstract}
British expansion in Sri Lanka was halted by the mountains in the centre of the island. The kings of Kandy guarded knowledge about topography and this led in part to the British army's defeat of 1803 . Within the Kandyan kingdom, boundary books and verses provide evidence of a vibrant tradition of oral knowledge about the land, linked with piety and history. When the British took control of the interior in 1815 Governor Barnes urged the necessity of a road to Kandy in order to open up the hills. Surveys were vital to this road and surveying was posited as a rational and heroic science. However, the British continued to rely on local knowledge in planning public works; they surveyed ruined tanks in the north-central provinces. British expansion therefore witnessed both competition and cooperation between different orders of knowledge. There were multiple encounters between knowledge, empire and the land.
\end{abstract}

On a trip to Ceylon in 1825 , Rev. Reginald Heber, the Bishop of Calcutta, took the recently opened road from the sea-side capital of Colombo to the hillside town of Kandy, in the company of the governor Edward Barnes. Barnes drove the Bishop in a bandy, while Mrs. Heber accompanied two of the main architects of the road and several other European gentlemen in a palanquin. Half way to Kandy, Mrs. Heber wrote: "we were met by an extraordinary personage, the second Adigar of Candy, followed by a numerous retinue, and preceded by one man carrying a crooked silver rod, and by another with a long whip, which he cracked at times with great vehemence; this

${ }^{1}$ This paper arises from a larger project on the environmental history of British colonisation in Sri Lanka. An earlier version was presented to the Imperial History Research Seminar at the Institute of Historical Research, London and the Commonwealth and Overseas Seminar, Cambridge. I thank participants for their comments. In particular I wish to thank David Arnold, Chris Bayly, Mike Lewis and Alan Strathern for their advice. 
is considered a mark of dignity among the Candians". ${ }^{2}$ The adigar or chief-minister was elaborately dressed, and Heber went into detail about this. Barnes and the Bishop dismounted from their bandy and exchanged pleasantries with the adigar. While no account is given of the conversation that passed between the two parties, it is striking that both British colonisers and Kandyan elites could use the new road as a site of procession. Eleven years after the construction of the Kandy road had commenced, Barnes' successor wrote triumphantly that it had become "a striking example of British science and energy"; those who built it were said to have furnished "to the natives a practical model of European skill". ${ }^{3}$ So what might this meeting between Barnes and the adigar tell us about the significance of roads to colonisers and colonised?

There is now a burgeoning literature on South Asia that seeks to address the relationship between knowledge and empire. ${ }^{4}$ Choosing between the concepts of imposition and dialogue, this field of scholarship views colonial knowledge as essential to political control. At issue however is what level of participation to assign to indigenous peoples, and how to relate existing traditions of knowing to the newly arrived colonial order of information. Bernard Cohn and Ronald Inden take a Saidian approach in urging that Britons surveyed, collected, chronicled and counted India so as to produce a cohesive unit of government. ${ }^{5}$ Christopher Bayly's work points attention instead to the trade in information between the East India Company and indigenous informants. ${ }^{6}$ These two information orders were entangled and the Company's rule depended on the efficiency of its links with local knowledge. Dissenting somewhat from this emphasis on colonial appropriation, Eugene Irschick's work on the environment of South India has suggested that British and local interpreters were equally involved in the production of new knowledge, and that it is unhelpful to label indigenous knowledge as separate from western forms of

\footnotetext{
${ }^{2}$ Amelia Heber, Narrative of a journey through the upper provinces of India from Calcutta to Bombay, I 824-I 825, with notes upon Ceylon (London, 1828), Vol. II, p. 244

${ }^{3}$ R. W. Horton to Viscount Goderich, dated 21 Nov. 1831, CO 54/112, The National Archives, Kew.

${ }^{4}$ For a good introduction to the history of knowledge and empire in South Asia see David Arnold, Science, technology and medicine in colonial India (Cambridge, 200o).

${ }^{5}$ Bernard Cohn, Colonialism and its forms of knowledge: The British in India (Princeton, 1996) and Ronald Inden, Imagining India (Oxford, 1990).

${ }_{6}^{6}$ C. A. Bayly, Empire and information: Intelligence gathering and social communication in India, I770-I870 (Cambridge, 1996).
} 
knowing. ${ }^{7}$ In fact Irschick contends that both coloniser and colonised participated in a dialogue which operated in the same epistemic field.

While it may be useful to speak analytically of the relationship between knowledge and empire, the easy traps into which an overgeneralised account of colonial information may fall is well illustrated by recent criticisms of the work of Edward Said. ${ }^{8}$ Knowledge is a slippery category; while the term discourse might emphasise knowledge as text, clearly knowledge can be articulated by artefacts and displays as well. ${ }^{9}$ While historians may prefer institutionalised knowledge as a subject of contextual study, knowledge also entered the public domain as popular information. ${ }^{10}$ Inspired by the work of Pierre Bourdieu, some recent attempts to characterise the history of knowledge have preferred to represent it not as cerebral, but rather as embodied in lived experience and collective action. ${ }^{11}$ A practice as simple as travelling on a road should now be seen as an example of knowledge in use. In other words, the relationship between knowledge and empire looks very different from the bottom-up to what it seems in high-brow intellectual circles. ${ }^{12}$ It is vital that we come to a balanced picture of the plurality of knowledges that were used to support and critique the colonial enterprise with different degrees of success by colonisers and colonised.

This essay only scratches the surface of these directions of inquiry; but it aims to study the early phase of British presence and expansion

${ }^{7}$ Eugene Irschick, Dialogue and history: Constructing south India, I 795-I 895 (Berkeley and Los Angeles, 1994).

${ }^{8}$ Edward Said, Orientalism (London, 1978). For incisive comments on why it is necessary to balance an emphasis on dialogue between indigenous and European knowledge with attention to power-relations see, Michael Dodson, 'Orientalism, Sanskrit scholarship and education in colonial north India, c. $1775^{-1875}$ ( $\mathrm{PhD}$ Dissertation, University of Cambridge, 2003).

${ }^{9}$ For an exploration of the links between artefacts, science and colonialism see the work of Nicholas Thomas, Entangled objects: Material culture and colonialism in the Pacific (Cambridge, 1991).

${ }^{10}$ As examples of institutionalisation: Lucile H. Brockway, Science and colonial expansion: The role of the British royal botanical gardens (New York, 1979) and Richard Drayton, Nature's government: science, imperial Britain and the 'improvement' of the world (New haven, 2000). For colonial popular science see: Sujit Sivasundaram, Nature and the godly empire: Science and evangelical mission in the Pacific, I 795-1850 (Cambridge, 2005).

${ }^{11}$ See Barry Barnes, 'Practice as Collective Action' in Karin Knorr Cetina, Eike von Savigny and Theodre R. Schatzi eds. The Practice Turn in Contemporary Theory, (London, 2001), pp. 17-28.

${ }^{12}$ For bottom-up relations between knowledge and empire see, Alison Winter, Mesmerized: Powers of Mind in Victorian Britain (Chicago, 1998), Chapter 8. 
in Ceylon, taking the uses of geographical knowledges in the public domain as its focus. ${ }^{13}$ For this period, it is my claim that competition and dialogue are helpful terms to employ in referring to the exchanges between colonial and local subjects. Politically, this was the time of the wars of Kandy when the urgency to consolidate British power over the highlands was manifest. In this context, the importance-or even lack-of British geographical knowledge was aptly demonstrated to the whole of the British army and its combatants in the mountains. After wresting control the British used several striking applications of science and engineering to wield power over their new found provinces. Yet these icons of colonial rule-roads and bridges-sometimes provoked violent schemes of sabotage from local inhabitants. It is my aim to elucidate a few of the most publicised moments when the relationship between knowledge and control was asserted as a means of political capital and resistance in Ceylon in the early nineteenth century.

Competition between different genres of British and Kandyan geographical knowledge was evident in several senses in this period. It may be argued, for instance, that Kandy was taken only after Kandyans and Britons competed for control of knowledge of the mountain terrain. The consolidation of colonial rule in the hills justified Governor Edward Barnes' extensive programme of public works and the road to Kandy was central to this. This network of roads relied on indigenous labour and on already existent pathways. ${ }^{14}$ Imperial roadbuilding operated within the framework of local knowledge, and sought to supersede it; the Kandy road trumpeted the superiority of British knowledge. But using the terminology of contests also helps recover the limitations of colonial science in early expansion. As this essay illustrates, grand projects that sought to display the utility of colonial knowledge failed when tunnels collapsed and roads were washed away by the rains. Financially and ideologically, the application of colonial

${ }^{13}$ For other work on the historical geography of Sri Lanka in this period see, James Duncan, 'Embodying colonialism? Domination and resistence in nineteenthcentury Ceylonese coffee plantations' in Journal of historical geography, Vol. 28, (2002), pp. 317-338 and James Duncan, 'The struggle to be temperate: Climate and 'moral masculinity' in mid-nineteenth century Ceylon' in Singapore journal of tropical geography, Vol. 2 1, (2000), pp. 34-47. See also James L. A. Webb, Tropical pioneers: Human agency and ecological change in the Highlands of Sri Lanka, I80o-I9oo (Ohio, 2002).

${ }^{14}$ The history of the Kandy road has not been written since this descriptive essay: W. Ivor Jennings, 'The opening of the Kandy road' in Ceylon journal of historical and social studies, Vol. 1 (1958), pp. 97-104. See also, G. P. S. H. de Silva, 'Beginnings of commercial road-passenger transportation in Sri Lanka' in Journal of the Ceylon branch of the Royal Asiatic Society, Vol. 36 (1991/2), pp. 96-107. 
science and technology was more often marked by disappointment than success in the early British period.

Yet the use of the idea of competition between different traditions of knowledge should not distance colonial networks from local webs of information. It is important to stress how information was shared between coloniser and colonised. Guides and informants were crucial to British geography, as were local peoples trained in western modes of surveying. Co-operation was particularly marked when it came to mundane technical information associated with public works: the essay ends with the account of how Britons appropriated engineering knowledge associated with the island's ancient civilisations, especially its dams. The undoubted contradiction in using both competition and co-operation to outline how colonial and local modes of knowledge engaged with each other, mirrors a nineteenth-century debate about the relative viability of reformist and orientalist models of British colonialism and their alternative conception of local knowledge. Historians who theorise the relationship between knowledge and empire should therefore keep in view how contemporaries themselves articulated the difference between colonial and colonised knowledge for political purpose.

In documenting competition as well as co-operation it is also my intention to destabilise the traditional dichotomy between western science and indigenous knowledge in at least two ways. Firstly, it is necessary to explore the common qualities of different traditions of knowledge. For instance, it is important to appreciate how both British and Kandyan engagements with the land operated on the basis of aesthetic judgement. The tradition of the sublime and an attachment to the thrill of being at the top of a mountain cut across accounts of colonial travellers and surveyors. The need to place the colonial science of cartography in a wider context of the history of aesthetics is well argued in Matthew Edney's book on the survey of India. ${ }^{15}$ An analysis of the poetic forms of Kandyan geographical knowledge finds a place here alongside a discussion of travel journals, in order to make the point that the genres of colonial and Sri Lankan knowledge were not dissimilar. In addition to this, it is important to stress that there were diverse genres of colonial information and diverse genres of

${ }^{15}$ Matthew Edney, Mapping an empire: The geographical construction of British India, I765-I843 (Chicago, 1997). Other work on cartography and empire includes: Anne Godlewska and Neil Smith eds. Geography and Empire (Oxford, 1994) and Felix Driver, Geography militant: Cultures of exploration and empire (Oxford, 2001). 
local information: religious and secular, elite and popular, urban and rural. The validity of a distinction between colonial and indigenous knowledge falls apart at both a higher and lower register.

I hope also to contribute to the historiography of British Ceylon. In the Oxford History of the British Empire, K. M. De Silva bemoans the lack of interest displayed by South Asianists with respect to the history of Sri Lanka. ${ }^{16}$ The most authoritative work on the British period continues to be the two-volumed overview written by Colvin R. De Silva. ${ }^{17}$ The ethnic conflict in Sri Lanka, however, has seen a resurgence of interest in history. The works of Lorna Dewaraja and Patrick Peebles, serve as effective starting-points for an analysis of British advance in Ceylon. ${ }^{18}$ Dewaraja has shown how the Kandyan kingdom went into decline in the eighteenth century, as the Nayakkar dynasty of Madura took control of the throne. Despite being alienated from the populace by language, religion and culture, the Nayakkar monarchs had a credible right to rule since their ancestors had been taken as wives by the Sinhala kings of Kandy. In this context they sought to stabilise their sovereignty by undertaking a wide-scale programme of cultural renaissance, but power inevitably slipped into the hands of feuding nobles. ${ }^{19}$ In 1796 , when the British took control of the

${ }^{16}$ K. M. De Silva, 'Ceylon (Sri Lanka)' in Robert Winks ed. Oxford history of the British Empire: Vol V, Historiography (Oxford, 2001) pp. 243-252. Throughout this essay I use Ceylon and Ceylonese as period terms for the British colony and its inhabitants; Kandy and Kandyans to signify the kingdom that fell to the British and its subjects, and Sri Lanka and Sri Lankans as the name given to the state and its citizens in its current incarnation. However Sri Lanka also appears as a name in the boundary texts discussed below. I have therefore used Sri Lanka sparingly to refer to pre-colonial times. I note that it is also the current term used by both Sinhalese and Tamils to refer to the island.

${ }^{17}$ Colvin R. De Silva, Ceylon under the British occupation, I 795-I 833 (Colombo, 1953$62), 2$ Vols. This set may in time be replaced by the two volumed history written by Michael Roberts, of which the first volume has just been published. Michael Roberts, Sinhala consciousness in the Kandyan period, I590s to I 815 (Colombo, 2004).

${ }^{18}$ Lorna Dewaraja, The kandyan kingdom of Ceylon, I 707-176o (Colombo, 1972) and Patrick Peebles, Social change in nineteenth-century Ceylon (New Delhi, 1995). There have also been some excellent recent articles on the British period by John Rogers. See: John D. Rogers, 'Caste as a social category and identity in colonial Lanka' in Indian Economic and Social History Review, Vol. 41, (2004) pp. 51-77, and John D. Rogers, 'Early British rule and social classification in colonial Lanka' in Modern Asian Studies , Vol. 38, (2004) pp. 625-647.

19 This view of Nayakkar rule has however been recently contested by scholars who allege that it over-emphasises the agency of the monarch, and that it imputes an anachronistic idea of ethnic difference to this period. See for instance: Anne M. Blackburn, Buddhist learning and textual practice in Eighteenth-century Lankan monastic culture (Princeton, 2001), R. A. L. H. Gunawardana, 'Colonialism, Ethnicity and the Construction of the Past: The changing 'ethnic identity' of the last four kings of the 
maritime provinces of Ceylon from the Dutch, the kingdom of Kandy was in internal strife.

The chief adigar Pilima Talauve, in a bid to take the throne, placed a young Nayakkar youth whom he intended to be a puppet as king. Yet this young man proved to have his own agenda and turned away from his allegiance to the adigar. Pilima Talauve then called on the British to intervene, hoping that they would crown him as king. By 1803 , the British had been convinced to go to war with Kandy, but were slaughtered in the highlands at the hands of forces loyal to the king, after the colonial army was taken with fever. Peasants loyal to the king then commanded a counter-invasion by attacking British territory in the maritime provinces. The Britons by these rather dramatic means learnt the necessity for more accurate information about geography and climate. ${ }^{20}$ In 1812 Pilima Talauve and many nobles were done to death. Having isolated himself from all classes of society, and having turned to drink, the king then opened himself to the ready conquest of the British. Having taken control of Kandy in 1815 , the British sought to appease the people of Kandy by promising to govern in accord with existent laws, while protecting the traditional rights of Buddhism. Their presence in the highlands was far from stable-as is demonstrated by the wide-scale revolt against colonial rule in $1817-$ 18. It is in this context that the British initiated a programme of mapping, public-improvement and road-building to bring the isolated towns of the highlands into a system of exchange and commerce, and to curb their rebellious temperament.

My analysis of the inter-relation between British expansion and the production of new geographical knowledge will begin, however, in the early battles, when the Kandyans had the initiative.

\section{The Land as Defence}

A mid-nineteenth century historian of Ceylon wrote that the mountains in the centre of the island formed a "species of natural circular fortification" which allowed the Kandyans to defy European

Kandyan kingdom' in Martin van Bakel, Renee Hagesteijn and Pieter van de Velde eds. Pivot politics: Changing cultural identities in early state formation processes (Amsterdam, 1994) pp. 197-211.

${ }^{20}$ For commentary on the wars of Kandy see, Geoffrey Powell, The Kandyan wars: The British army in Ceylon, I 803-I 818 (London, 1973) and, Channa Wickremesekera, Kandy at war: Indigenous military resistance to European expansion in Sri Lanka, I594-I8I8 (Colombo, 2004). 
modes of warfare for three centuries. ${ }^{21}$ In his popular commentary on the island, Robert Percival noted that the inaccessibility of the interior was said to have even "rendered the lines of [Kandyan] character more bold and prominent," in contrast with "the subjection and tranquillity of the lowlanders" ${ }^{22} \mathrm{He}$ noted that the "excessive thickness of the woods ... causes heavy fogs and unwholesome damps to prevail ... hence the night is constantly attended with excessive cold damps, which are succeeded by days equally noxious from their hot and sultry vapours". Europeans who were brought into contact with this climate often fell ill with debilitating "hill or jungle fever". ${ }^{23}$ In a climate and terrain such as this, the Kandyan forces had a natural advantage over their British opponents. ${ }^{24}$

In 1803 , when the British waged war with the Kandyans, the lack of accurate maps proved perilous. According to Major Arthur Johnston of the Third Ceylon Regiment, the guides that could be procured were often "in the pay of the enemy" and could "tangle the troops in the forest", and then leave them to their fate. ${ }^{25}$ But even if the guide was a Muslim, therefore friendly to the British, he might be perfectly well acquainted with the high roads that could be used for travel in daylight and yet be of no use in helping an army at night. "In these thick forests," the Major wrote, "even in the brightest moon-light it is extremely difficult, and often impossible, for one not perfectly acquainted with the track to discern the foot-path" ${ }^{26}$ The usual technology of the compass could also provide no assistance: "it being impossible to march in a direct line through a thick forest, intersected in many places by rivers and swamps ..."27 When Kandy did eventually fall in 1815 , Captain De Bussche, who held the post of Deputy Adjutant General, wrote how geographical information had played a crucial role

${ }^{21}$ Henry Charles Sirr, Ceylon and the Cingalese (London, 185 , reprinted, New Delhi 1991), Vol. 1, p. 219.

${ }_{22}$ Robert Percival, An account of the island of Ceylon containing its history, geography, natural history (London, 1805), p. 169.

${ }^{23}$ Ibid. p. 168.

${ }^{24}$ Wickremesekera, Kandy at war, p. 151 . James Duncan has also documented how tropical nature was seen to be a moral adversary of the British, and how local peoples used knowledge of the landscape as a tactic of resistance in coffee plantations. See, Duncan, 'Embodying colonialism' p. 326; and Duncan, 'The struggle to be temperate' p. 35 .

${ }_{25}$ Arthur Johnston, Narrative of the operations of a detachment in an expedition to Candy in the island of Ceylon in the year I 804 (London, 1810), pp. 129-30.

${ }^{26}$ Ibid. p. 127.

${ }^{27}$ Ibid. p. 128. 
in the victory as "the different divisions of the army were supplied with excellent charts, and the most distinct information respecting the strengths of the passes leading into the interior". ${ }^{28}$

Even as the British conquest of Kandy depended on the acquisition of geographical knowledge and guides, Kandyan resistance to encroachment involved the protection of information about the interior. It was noted for instance that "when an ambassador was sent from any European government to the King of Candy, he was watched with all the strictness and jealousy which the suspicious temper of uncivilized nations dictates". ${ }^{29}$ According to Major Johnston, on the paths to the interior, "gates [were] fixed and guards stationed, to prevent the entrance of strangers, and to examine all passengers", and this was so as to "watch the ingress and egress of their territory". ${ }^{30}$ It was therefore the strategy of the Kandyan kings to keep the roads nearly impassable so that their territory was inaccessible. ${ }^{31}$ The strategies of war deployed by the Kandyans also point to geographically inspired resistance.

The colonial sources for this period have copious descriptions of how Kandyans went to battle; the most detailed is Johnston's account of the failed war of 1803 . The Major wrote that the Kandyans harassed the British army while they were on march, by cutting off supplies, interrupting communication between the divisions and "occupying the heights which command the passes, from whence they fire in perfect security behind rocks and trees". ${ }^{32}$ While using the natural features of the land to hide themselves, Kandyans made a habit of trapping Britons inside the mountains so that they could not escape. They were "certain that the diseases incident to Europeans in that climate, and the want of provisions" would soon oblige the British to fall back. So even as Britons were on the march, the Kandyans blocked up the routes of retreat and when the British attempted to return to their seaside strongholds "encumbered by a long train of sick and wounded" the Kandyans would finally attack the Britons and have the upper-hand. ${ }^{33}$ The Kandyans' familiarity with their environment was such that it

${ }^{28}$ L. De Bussche, Letters on Ceylon, particularly relative to the kingdom of Kandy (London, 1826), p. 20.

${ }^{29}$ Percival, An account, pp. $163-4$.

${ }^{30}$ Johnston, Narrative, p. 3 .

31 See Jonathan Forbes, Eleven years in Ceylon, (London, 1840), Vol. 2, p. 66.

32 Johnston, Narrative, p. 5 .

33 Ibid., p. 6. 
was reported that they cut paths to right and left through the jungle so that they could outflank the invading British army. ${ }^{34}$

In addition to using geography for military purposes, the Kandyans relied on nature for ammunition and supplies. Johnston notes, for instance, how each village chief on receiving orders from his superior "summons every third, fourth, or fifth man, according to the nature of his instructions, and proceeds with his feudatory levies to the place of rendezvous". Each soldier in addition to a musket took with him "a leaf of the talipot tree" which could serve as an umbrella and a tent, when the broad ends of the leaf were tied together. Their chief food was a grain that grew on the hills with little cultivation, therefore negating the necessity for supplies to be carried across a distance. Johnston added that "two or three cocoa-nuts, a few cakes, made of the grain I have just described, and a small quantity of rice, compose the whole of the soldier's stock for the campaign". ${ }^{35}$ In this narrative, the Kandyans themselves appear as creatures of nature. For example, Johnston describes how a local soldier "crawls through the paths in the woods, ... or climbs the mountains and places himself behind a rock, or a tree, patiently to await the enemy's approach" ${ }^{36}$ Once battle was won, it was common practice amongst the Kandyan troops to heap the enemy's heads as war trophies; Sinhala war poems liken these collections of heads to piles of coconuts. ${ }^{37}$

Topographical information and territorial expansion operated side by side, and resulted in a contest between the colonisers and the Kandyans about what they knew about the land and how they engaged with nature. Faced with this contest, the British portrayed the inhabitants of the interior as isolated and unhappy, awaiting British liberation when open commerce and exchange could begin. As a means of hiding the embarrassments of their faulty knowledge of the environment, Percival noted: "the oppression of their governors, the constant dread of Europeans, and the superstitious fears arising from the nature of their climate, which continually haunt them, deprive this isolated people of all the enjoyments which seem congenial to their situation" ${ }^{38}$ The British saw it as their moral responsibility to break the geographical isolation of the Kandyans and bestow them with benevolent government.

\footnotetext{
${ }^{34}$ Wickremesekera, Kandy at war, p. 141.

${ }^{35}$ Johnston, Narrative, p. 9 .

${ }^{36}$ Ibid. p. 10.

${ }^{37}$ Wickremesekera, Kandy at war, p. 146.

${ }^{38}$ Percival, An account, p. 185 .
} 


\section{Making Boundaries}

The Kandyan experience of war illustrates the strengths of local knowledge and the limitations of European cartography. However, it is still important to recover as much as possible about what the inhabitants of the island knew about the land prior to British conquest in order to contextualise the advance of colonial knowledge. By using a series of sources concerned with boundary divisions in early modern Sri Lanka, which are just coming to the attention of Western academics, I hope to suggest the vibrancy and popularity of a genre of sacred geographical knowledge. ${ }^{39}$ This tradition of information about the land provides a suitable context for appreciating how Kandyan troops mapped their environment. It is a genre of information that was linked to the Kandyan court but that took on a lively existence in rural contexts.

The sources which will be used in the discussion that follows are of two types. Firstly, the kadaim, or boundary books, are state documents which describe the three main divisions of the island of Sri Lanka, and which were in the custody of the lekam-gey-attan or functionaries to the secretariat at court. ${ }^{40}$ Though the tradition of fixing boundaries has an ancient history in Sri Lanka, it is striking that the making of kadaim books appears to be an early-modern preoccupation. No kadaim book has been discovered which predated the period when Gampola was the capital in the fourteenth century. ${ }^{41}$ Information about territorial boundaries, historical anecdotes and comments on social organisation are seamlessly intertwined in these books. I will also use a set of sources called the kadaim-kavi, or boundary verses, which were recited at village ceremonies or to entertain local chiefs, often as a means of publicising erudition. Again these were mostly composed during the period prior to British advent. Gananath Obeysekere has suggested that the preponderance of boundary texts in the early-modern period is a reaction to the redrawing or rearranging of boundaries by the

${ }^{39}$ I am drawing on the work of H. A. P. Abeyawardana, Boundary divisions of mediaeval Sri Lanka (Colombo, 1999), which is a translation of the Sinhala version first published in 1978. A selection of these texts will also be published soon in Sinhala under the editorship of Gananath Obeyesekere. Sources that have been translated into English may also be followed up at: H. C. P. Bell, Archaeological Survey of Ceylon, Kegalle District (Colombo, 1892); A. C. Lawrie, A Gazetteer of the Central Provinces of Ceylon (Colombo, 1896) and W. A. De Silva, 'Sinhalese Vittipot (Books of Incidents) and Kadaimpot (Books of Division Boundaries)' in Journal of the Royal Asiatic Society Ceylon Branch, Vol. 3o, (1927), pp. 303-325.

40 Abeyawardana, Boundary divisions, p. 9 .

${ }^{41}$ Ibid., p. 7. 
Portuguese. ${ }^{42}$ It is plausible that the arrival of European geographical knowledge saw a resurgence and acceleration of interest in boundaries amongst people ruled by the king of Kandy.

In the kadaim books, Tri Simhale, which denotes the entire island, is divided into three principalities or kingdoms, namely Maya, Pihiti and Ruhunu. The oldest kadaim book, Sri Lamkadvipaye Kadaim, divides the entire island into 114 ratas or countries; Maya has 28 ratas, Pihiti has 43 ratas and Ruhunu has 43 ratas. Boundary pillars mark off the limits of particular ratas. Take the description of Bogambara rata in the Sri Lamkadvipaye Kadaim: 'For the four boundaries, stone pillars are placed on which are carved the figure of bo-leaves' ${ }^{43}$ Elsewhere this text makes note of other types of boundary pillars: Mayadunna-rata is bounded by 16 stone pillars bearing the figures of trees; Navayotnarata has 16 stone pillars bearing the inscription of cobras; Devamaddarata has 16 pillars on which were carved figures of parrots; in Amadarata 'to the east and west, three boundaries are marked by inscribed stone pillars placed on the tank bunds', and in Elasara-rata, 'a giant canal has been built and in the four corners are placed boundary stone pillars upon which are indited the figures of an arrow'. ${ }^{4}$

H. A. P. Abeyawardana, in his commentary on these texts, has argued that the meaning of these symbols was easily comprehended by observers: for instance the sight of the cobra could denote protection, and the figures of the sun and moon could denote that the gods had decreed that these boundaries would last as long as the sun and moon. ${ }^{45}$ But there are exceptions to this pattern: some pillars were hidden and constituted secret knowledge about boundaries. In addition to this, certain boundary pillars indicated the name of the region they marked out. For instance, the figure of the horse on a stone pillar denoted a region taking its name from the horse; the figure of a squirrel, a region taking its name from the squirrel; the figure of the moon, a place taking its name from the moon. The Sri Lamkadvipaye Kadaim notes an intention on the part of the rulers to have these boundary pillars last unaltered for eternity. ${ }^{46}$

In addition to boundary pillars, natural features of the land were also used as boundary marks, and this indicates that rocks, mountains

${ }^{42}$ Gananath Obeyesekere, 'Rare historical manuscript series' (Manuscript), p. 24.

43 Abeyawardana, Boundary divisions, p. 193.

${ }^{44}$ Ibid., p. 202.

${ }^{45}$ Ibid., p. 148 .

${ }^{46}$ Ibid., p. $15^{1 .}$ 
and rivers were seen as stable features of the landscape. Marks in trees and rocks may have been renewed from time to time in order to make them endure. ${ }^{47}$ Take the example of this kadaim-kavi, which describes the boundaries of Muvatapattu:

From the archers' rock to the Valimaluva (sand-strewn) rock, From that to the next upon which are engraved oxen hooves, Then to the nagara-letter carved rock,

Past the three-pronged gorge to Kalukohovila pool;

Beyond Dunukeyiya rock, proceed to a point, Below the rock fortress that flies the war flag, Past the three-swords-engraved rock, reach, The wooden pond frequented by elephants.

These verses do not illustrate that local peoples had a simplistic view of nature. Rather, they demonstrate that they engaged with the land symbolically, and that they read the land in order to come to an idea of its natural boundaries. The rocks and waterfalls that appear in the kadaim-kavi are therefore laden with historical and religious meaning: there are references to a rock from which King Rajasimha watched a battle ${ }^{48}$; a cave which sheltered a sacred relic ${ }^{49}$ and a mountain which was full of incense. ${ }^{50}$ At the same time peculiarities in nature were used as points of attention in marking a boundary or path. One poem refers to a creeper-laden tre $e^{51}$ and another to a stony cotton field frequented by a leopard. ${ }^{52}$

The geographical knowledge demonstrated by the kadaim pot and kadaim kavi is closely linked with piety. The Tri Simhale Kadaim makes note of the sacred places in each of the regions. The misdeeds of King Kalanitissa are said to have changed the geography of Mayarata: 'Because of the wrong doings of King Kalanitissa, the sea engulfed five leagues of land and kept only one league'. ${ }^{53}$ The 'sacred places of Ruhunu-rata' include several vihara, or temples, and the 'Sripadasthana on the Samanala mountain where Buddha placed his foot-mark which has 216 auspicious signs and the place is visited for

${ }^{47}$ Ibid., p. $5^{2 .}$

${ }^{48}$ Ibid., p. 222.

${ }^{49}$ Ibid., p. 221.

${ }^{50}$ Ibid., p. 219.

${ }^{51}$ Ibid., p. 221.

${ }^{52}$ Ibid.

${ }^{53}$ Ibid., p. 205. 
worship by pilgrims ...,54 The implication is that these boundaries are sacred divisions of the land. In fact the whole of Sri Lanka appears in these texts as a sacred land. Lakvidiya begins: 'Adoration to the Buddha. Having subdued the yakkhas here/In the past the Buddha made this land/The home of the Triple Gem/Hence the lineage of the righteous rulers/Firm in the Dhamma/Was established in the Simhala'. 55

This geographical knowledge was meant to be easily accessed. The versifier of one kadaim-kavi noted that he had derived his information from "following an ancient book", which was copied so that everyone could know the path. ${ }^{56}$ Indeed it is possible that the kadaim-kavi fitted into a culture of entertainment. The kadaim-kavi which describes the boundary of Paranakuru Korale takes the form of a riddle:

Reptiles and snakes gathered in a cloth bag,

Bloody but sumptuous food kept atop a rock,

Sweet and tasty betel leaves placed below the rock,

And old elephants have added their rut to the heap.

This riddle is solved by the realisation that each line contains a pun. For instance, in line two, food (bata) with blood (le) upon the rock (gala) indicates the rock named Batalegala. And so the reply is given as following:

Friend! I reckon that what you are saying is that, From Nayiyankada is a difficult climb to Batalegala, But, there is much fun to sport on the Rahala rock, Is not the Parana kuruva amidst these three?

It has been argued that these types of texts were "written in simple prose or verse by local intelligentsia (scribes, headmen, nobles and even ordinary villagers) $" .{ }^{57}$ If this is confirmed, then we have evidence for an extremely popular genre of geographical knowledge. The language of these poems supports this view; the Sinhala is colloquial and related to the diction of rural people. ${ }^{58}$

The inter-relationship between topography, history and religion suggests that geographical knowledge was deeply interwoven into Sinhala culture. It wasn't an elite form of information. These traditions

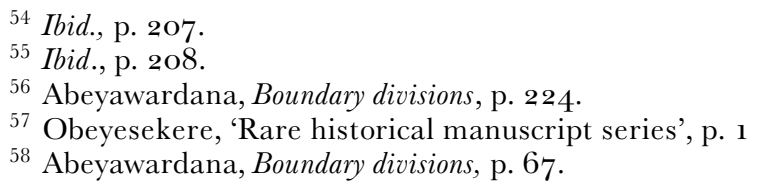


allowed the land to become a repository of meaning and geographical features were approached with veneration by local peoples. The Kandyan troops did not merely know their environment better; they observed the land's contours, history and sacredness.

\section{Amateurism to Commerce}

As early as five years after the British took control of the maritime provinces from the Dutch, they had established a Survey Department to bring their new acquisition into the bounds of known knowledge. The Government Gazette of the $5^{\text {th }}$ of April 1802 included the following: "Notice is hereby given, that in the measurement of land in the British territories of Ceylon, the standard measures of Great Britain, alone will ... be made use of". The new units of measure were then specified: a chain was equal to four poles or perches, and could be divided into one hundred links. ${ }^{59}$ After paying attention to the relatively poorly documented traditions of Kandyan geography in pre-colonial times, the confidence of this statement is rather startling.

Joseph Jonville, the first Surveyor-General, who took up his post in 1802 , was entrusted with the task of surveying the land so as to assist the government in debates concerned with the ownership of property. Yet Jonville, being of the enterprising sort, was quickly distracted by the need to make "a general map of the Island of Ceylon with that exactness which alone can render it useful to Government and at least interesting to individuals fond of the Arts and Sciences" ${ }^{60}$ The size and scale of this map was dictated by its intended use in administration. It was made to be as large as 90 to 100 feet in length; so that various provinces could be considered separately and individual villages could be inspected, cultivated land was marked as distinct from uncultivated. Of course such a survey depended on trained observers and proper instruments, neither of which Jonville had in his possession. So he wrote: "Permit me to represent to you that it is impossible to procure instruments here, which are absolutely wanted..." Undeterred Jonville made his own instruments; by cutting a glass tube he made several levels, and by engraving on copper he manufactured small scales. This amateurism came to characterise British surveyors from Jonville right up to the 183 os.

${ }^{59}$ The Ceylon Government Gazette, 5 Apr. 1802.

${ }^{60}$ Cited in R. L. Brohier, Lands, maps, surveys: A review of the evidence of the land surveys as practiced in Ceylon (Colombo, 1950), Vol. 2, p. 15. 
Soon after the acquisition of the Kandyan kingdom in 1815 , for instance, a military survey of the interior was undertaken by Captain John Fraser. Lieutenant Skinner, who was employed under Fraser, was directed to examine the great mountain chain surrounding the Upper Kandyan Provinces, "sketching its principal features and ramifications, with as much minuteness ... and tracing and laying down its passes and defiles, and the paths and roads that lead through them". ${ }^{61}$ The need to represent Kandy on paper was militarily strategic, especially given the impact that a lack of geographical information had on the British in the first decades of the century. Skinner was directed to use the method of triangulation for his cartography; he was given the best theodolite, but no further training. In his autobiography he writes:

I was unfortunately too proud to acknowledge my incompetence, but gained immense strength from the faith my old chief, Sir Edward Barnes [the Governor] placed in me when he appointed me to the QuartermasterGeneral's department. In reply to my protest that I knew nothing of scientific duties, he said, "Do you think I do not know as well as you do. Will you try to qualify yourself?" "Yes certainly I will Sir". ...With the recollection of his piercing eye which went through me ... I shut myself up in a room with a theodolite and Adams on Instruments, took it entirely to pieces, put it together again, and learnt the use of all its parts ... I next took my new friend, the theodolite, to the western extremity of my base line, and took many complete series of observations round the circle, when I found that I gained by repeating them a certain coincidence in my angles. ${ }^{62}$

Behind the presentation of a theodolite to the untrained Skinner was a belief in the rationality of a Briton to bring the unruly territory of Kandy under the cool gaze of science. Yet it was requisite that Skinner emphasised his hard work to gain his place as a hero. $\mathrm{He}$ wrote therefore that he "never knew the shelter of a roof between four or five o'clock in the morning till seven in the evening". He had often gone without provisions when surveying. Once over a two month period he had "only five miserable chickens, three of which had died from the rain and cold on their way up to the Peak ..." His heroism arose not only from his ability to map the environment, but also from his aptitude for controlling his body. He observed: "All the liquid I took during the day did not exceed one imperial pint; this regime brought me

${ }^{61}$ Thomas Skinner, Fifty years in Ceylon: An autobiography (London, 1891, reprinted New Delhi, 1995), p. 170.

${ }^{62}$ Ibid., p. 173 . 
into such splendid working condition that I could outrun everyone" ${ }^{63}$ At night he lived in a tent composed out of "five sheets of tallipot leaf, stitched together" which contained a "little camp bed, a small camp table and chair". ${ }^{64}$ So Skinner concluded: "it was precious hard work, delightful to think of in the retrospect". ${ }^{65}$

While this hagiographic rhetoric would have us believe that new maps and surveys were the result of lone individuals, this was never the case. In an aside, Skinner noted how the inhabitants of the interior referred to him as "Cannade Mahotmia", or Gentleman of Instruments. As opposed to the objective man of science, Skinner presented his audience as bemused by the apparatus of knowledge. Major Forbes also drew attention to the bewilderment of the local people with regard to the technological prowess of the British; the theodolite was said to have attained "an extraordinary character" and "the ticking of the watch, and the turning of the compass in the theodolite, seemed to the Kandians to be direct vitality". ${ }^{66}$ Despite this stereotypical trope of distancing, it is important to stress how surveyors relied very practically on colonised labour for the purposes of conveyance. In 1812 , George Hayster, Civil Engineer, wrote:

I beg leave to represent to you that I have been obliged to advance between 4 $\& 5$ oo Rix Dollars to my Palankeen boys, coolies \&c \&c about to attend me in surveying the Giant's Tank and as Government have been pleased to decide that my travelling expenses should be paid, in consequence of the low salary I receive (viz) that of Assistant Civil Engineer, although I am now called upon to perform a more arduous and responsible service than has yet occurred in this island in the Civil Engineer's Department. ${ }^{67}$

The surveyor therefore did not travel alone: he was attended with a retinue of local labourers, who were eventually erased from the account. Yet, as this letter hints, the financial constraints of crown rule meant that the Survey Department could not be expanded with the recruitment of skilled Europeans. In the context of drives for economy, surveyors had to train local people in the art of using instruments to map the land. In 1833 , for instance, Captain G. Schneider, reported how he had acted as a "teacher of mathematics and surveying" and that those who

${ }^{63}$ Ibid., pp. $178-9$.

${ }^{64}$ Ibid., p. 176 .

${ }^{65}$ Ibid., p. 174.

${ }^{66}$ Forbes, Eleven years, Vol. 2, p. 87.

${ }^{67}$ George Hayster to Chief Secretary of Government, dated 5 Sept. 1812, Lot 6/259, Sri Lanka National Archives, Colombo. 
had been instructed by him had since been employed as surveyors. ${ }^{68}$ When Skinner retired, 1598 chiefs and headmen signed a memorial letter, which commended him for the encouragement he held out to local talent "by the admission of young men into the Government Factory as apprentices, with a view to qualify them as practical Engineers ..." 69 Local peoples were co-opted then to the task of extending British knowledge. Surveying the land did not see a straightforward influx of Western observers, it relied on indigenous populations.

Despite the presentation of surveying as specialist science, it seems to have a functioned as an aggrandised mode of colonial information gathering and to have had a commercial character. While collecting information about the land, surveyors were instructed to observe people and their political organisation also. In instructing Captain Schneider to survey the ruined tanks in north-western territories, Governor Maitland wrote that he should "be extremely attentive of the general feeling of the inhabitants" so that he could report back any information that it was fitting for the Government to possess. ${ }^{70}$ The manner in which surveying intervened in colonial governance, is best illustrated by some instructions given to surveyors by P. A. Dyke, the Government Agent of Jaffna. Dyke urged that headmen be included in surveys, and noted that "more difficulties far more serious than will be readily supposed" might arise if they were excluded. He stressed that even if they proved troublesome or intrusive, "their formal participation or co-operation or at least congizance" of the manner and results of the survey were crucial for the purposes of governance. ${ }^{71}$ Towards the middle of the nineteenth century, the sale of land assumed by the crown was expected to generate a sizeable payment and in this context surveying was further moulded by the colonial regime. In January 1842 , the Surveyor General advised the Government that crown lands in the neighbourhood of Colombo, Kandy, Galle and Jaffna, and close to the high roads and navigable rivers should be surveyed in small allotments and prepared for sale. ${ }^{72}$ By 1844 , Dyke could report that the "people of the country"

${ }^{68}$ Copy of letter from G. Schneider, dated 1oth February 1833, CO/54/127, National Archives, Kew.

${ }^{69}$ Skinner, Fifty years, p. 227.

${ }^{70}$ Governor Maitland's instructions to G. Schneider, CO/54/127, p. 305, National Archives, Kew.

${ }^{71}$ P. A. Dyke to the Surveyor General, dated 9 Jan. 1845, Lot 10/115, Sri Lanka National Archives, Colombo.

${ }^{72}$ Surveyor General to the Colonial Secretary, dated 5 Jan. 1842, Lot 10/115, Sri Lanka National Archives, Colombo. 
were asking to purchase lands, but cautioned that inhabitants were generally occupied in "removing their fences and other landmarks and taking in more or less of the waste lands adjoining". ${ }^{73}$ An improved survey was said to be what could "check these parties and ward off the ultimate consequences from them of serious detriment to the public interest". ${ }^{74}$

British surveys were testaments to the authority of the colonial state over its territories. In Skinner's self-presentation it is possible to trace the amateur Briton, who without any training and whilst undergoing every hardship, could conquer the land and reduce it to a neat map. New maps of Ceylon were political levers to British power, yet they functioned within the social fabric of crown rule. Surveyors relied on colonised labour, and fashioned local peoples to perform the function of collecting information about the land. Geographical mapping could not usurp systems of governance and indirect rule. And ultimately, the utility of geography lay not in its demonstration of rationality, but in its ability to add to the coffers of the state.

\section{Cartography's Aesthetic}

It is easy to place the growing confidence of British surveying-as it moved from early amateurism to mid-century commercialism-in opposition to Kandyan engagements with the land. Yet it is vital that we do not take the rhetoric of objectivity that surrounded colonial cartography too seriously. It is necessary to place any discussion of British surveying in the context of a wider account of colonial engagements with the land in Ceylon, for instance leisured travel.

For example, travellers were encouraged to envisage the island as one vast garden awaiting exploration. Rev. James Cordiner, the island's first British chaplain, noted that a journey in Ceylon may be "compared to an excursion in a large park or garden where there are no artificial walks". ${ }^{75}$ Behind this analogy was a sense of ownership of the land. Elsewhere in his book, Cordiner immediately followed his description of Ceylon as a garden with a copious list of commercially viable plants to be found in it. ${ }^{76}$ Yet it is important not to reduce the

${ }^{73}$ P. A. Dyke to Colonial Secretary, dated 24 Dec. 1844, Lot 10/115, Sri Lanka National Archives, Colombo.

${ }^{74}$ Ibid.

${ }^{75}$ James Cordiner, A description of Ceylon (London, 1807), p. 16.

76 Ibid. p. $344 \mathrm{ff}$. 
conception of Ceylon as garden to an expression of commerce; it also speaks of how scientific improvement could work concurrently with aesthetics. For instance, Henry Sirr noted that along the coast of the island, "the hand of nature and of art appear to combine to make the vista as glorious as it is possible to conceive ..."77 In a classic expression of how the introduction of British manners and customs could improve the land, Pridham noted that there was no scenery "more picturesque than the river near Baddegama". The writer's peculiar interest in this site originated from a comparison with England: "the stream with its grassy banks, the green meads, and the woody hills around forcibly recall to mind the scene presented by the Thames in the vicinity of the Richmond". This clue is important because the analogy with a park supposes an affinity between the green pastures of Britain and Ceylon.

Yet primary to this image was a belief in the importance of exploration. British travellers were in fact as attached to the mountains of the interior as the Kandyan inhabitants who lived there. The mountains marked the limits of their travels and the goals that motivated exploration. Rapturous descriptions of the sights that awaited explorers at the top of a mountain are common in travelogues. A striking example is John Davy's description of the view from Adam's Peak: "It looked like a map, laid out on a magnificent scale, with a glow of colouring, warmth of light, and charm of landscape, that we rarely see combined, except in the paintings of the first masters". ${ }^{78}$ British attachment to the view at the top of mountains is also evinced in their critique of Dutch houses built at the foot of hills. Leisure houses built by the previous colonisers were said to lie in "low, sheltered, often swampy positions, where the only object to be seen is a stagnant pool" while British governors and residents built their abodes "on the summits of cleared eminences, where refreshing gales allay the fervour of the torrid zone, and the eyes are delighted with the rich prospects and perpetual verdure ..."79 Robert Percival noted in the meantime that the towns of Ceylon, built by local rulers, "look more like a number of distinct houses scattered up and down in the midst of a thick wood or forest". ${ }^{80}$

The longing to make the mountains accessible led to Barnes' ambitious programme of road construction. Striking here is the

${ }^{77}$ Sirr, Ceylon and the Cingalese, p. 34 .

${ }^{78} \mathrm{John}$ Davy, An account of the interior of Ceylon and of its inhabitants (London, 1821 ), p. 361 .

${ }_{79}$ Cordiner, $A$ description, p. 184.

${ }^{80}$ Percival, An account, p. 126. 
extent of commentary on what could be seen from the road; the new highways seemed to open up the park of Ceylon. Travellers were asked to contrast the thick forests on either side with the powers of colonialism symbolised by the road. "Far as the eye can reach, the road winding through the wilderness of jungle, is distinguishable; and this indication of the presence of civilized man affords a striking contrast to the wildness of the mountain scenery around. The more you gaze on the wild landscape, the more you feel inclined to appreciate at its true value the enterprise and labour necessary for the formation of a carriage-road". ${ }^{81}$ Roads without a view, in the meanwhile, were criticised for being dreary. Charles Pridham noted that even local peoples referred to the region traversed by the road from Anuradhapura to Arippu as desolate. ${ }^{82}$

The manner in which roads served as a platform from which to observe the land, while providing the opportunity for a panoramic vision, is illustrated by this late nineteenth century poem by V. M. Hamilton and S. M. Fassoon:

They stretch like Roman roads of yore

O'er swamp and plain, from shore to shore

Up in the clouds they may be seen,

Deep cut in side of steep ravine,

Twisting and turning, in and out,

The mountains rocky slope about;

Now hidden from your wondering sight,

Now terraced round some awful height,

Whose massive overhanging brow

Threatens to crush the valve below

And on these roads the passer-by

May see much to delight the eye

If nature is his special craze

'Tis here displayed in every phase-

Jungle dark and palm-trees high,

Bold mountain peaks against the sky;

Glimpses of valleys far below,

All bathed in sunset's purple glow. ${ }^{83}$

Britons therefore sought to conquer the mountains and link the island's provinces with roads that would ease the burden of travel. Conceptions of the land were not restricted to the observations and

${ }^{81}$ Augustus De Butts, Rambles in Ceylon (London, 1841), p. 113.

${ }^{82}$ Pridham, An historical and statistical account of Ceylon, Vol. 2, p. 527.

83 'On the way up country' in V. M. Hamilton and S. M. Fasson, Scenes in Ceylon.

Twenty cartoons with descriptions in verse (Colombo, 1881). 
measurements of surveyors; the early nineteenth century witnessed a burgeoning tourism across the new colony. Travellers combined an appreciation of science with an appetite for aesthetics; commercial improvement and flights of the imagination were linked. These sources are very useful in destabilising a strict dichotomy between the modes of operation of British and indigenous geography.

\section{The Grand Military Road}

If there is one Briton who epitomised the programme of roads in Ceylon it was Governor Edward Barnes who took up his position at the head of the colony in 1820 , five years after Kandy had fallen. Barnes was trained as a soldier and, having taken a tour of the island, his immediate view was that a road to Kandy was the most crucial improvement necessary to secure the stability of Ceylon. By analysing the ideological and financial agenda that lay behind the construction of this road, it is possible to show how unsuccessful the British were in deploying their geographical knowledge.

The need for this road arose in part out of a contest between British and local demonstrations of power over the land. One of the ancient accounts of the island held that it would never be subjugated "until the invaders bore a hole through a mountain that encircled the Kandian capital". ${ }^{84}$ In building the Kandy road, the British made certain therefore to construct a tunnel at Kurunagala. In fact Barnes, when accompanying the visiting Bishop Heber, passed through this tunnel and made "the Caffres set up a yell, which reverberating against its roof and sides, had a most savage wild effect". ${ }^{85}$ It is clear that he delighted in how his efforts had demonstrated the superiority of British control of the land; in the words of one commentator the local people on observing the tunnel believed "that it is [was] their khismet (destiny) to submit to foreign domination". ${ }^{86}$

By attending to Barnes' letters to the Secretary of State in London, it is possible to recover the practical agenda that underlay the construction of the Kandy road. Three months after taking his position, Barnes brought the Ceylon Pioneer Lascars, Engineer Pioneers, Quarter Master General's Pioneers and Commissariat

\footnotetext{
${ }^{84}$ De Butts, Rambles in Ceylon, p. 169.

${ }^{85}$ Heber, Narrative, Vol. 2, p. 255.

${ }^{86}$ De Butts, Rambles in Ceylon, p. 169.
} 
Coolies together into one unit. He wrote that this would enable local people to work under European supervision, thus circumventing the difficulties that Europeans encountered while being employed in construction in a tropical climate. ${ }^{87}$ Having had the path of the proposed road traced, Barnes wrote to Lord Bathurst that the intended road "would consolidate the new with the old provinces; improve the commercial intercourse of the two, remove the principal difficulties that were experienced in the late military operations ... and diminish the vast expense in the conveyance of the commissariat supplies". There were therefore two ambitions that motivated the Kandy road: the display of power in fulfilling a local myth; and the betterment of British finances in Ceylon.

Despite this optimism, a proper road to Kandy took much longer to complete than anticipated. In 1822, while Barnes was away in India serving as Commander-in-Chief for ten months, Governor Edward Paget wrote to Bathurst: "The road now open for Carriages thro' the Seven Korles to Kandy requires much labour still to render it permanent throughout or capable of resisting the torrents of rain which fall twice a year ..." Even in 1833 , Governor Horton could still submit a bill for repairs to the Kandy road; he explained that it had been washed away by the rains. ${ }^{89}$ Britons therefore found it difficult to apply their science in a tropical climate. This is perhaps best illustrated by the plight of European officers, who continued to suffer in the heat, despite the reorganisation of the Pioneer Corps. Paget wrote, for instance, that they sacrificed their health and lives by "a continual exposure to the ardent heat of the sun in its highest elevation and never having any relaxation from fatigue, but when forced from the scene of their labours to confinement in sickness". ${ }^{90}$

The tale of Captain Dawson, one of the surveyors who had traced the line of the Kandy road, and then expired from ill health in 1829 , caught the imagination of the Anglo-Ceylonese community. Major Jonathan Forbes wrote that when he took the road to Kandy in 1828 , Captain Dawson was still "in rude health and buoyant spirits", but

${ }^{87}$ Despatch from Edward Barnes, dated 19 May 1820, CO 54/77, National Archives, Kew.

${ }^{88}$ Despatch from Edward Paget, dated 29 May 1 822, CO 54/82, National Archives, Kew.

${ }^{89}$ Despatch from R. W. Horton, dated 25Jul. 1833 , CO 54/1 29, National Archives, Kew.

${ }^{90}$ Despatch from Edward Paget, dated 1 Jun. 1822 , CO 54/82, National Archives, Kew. 


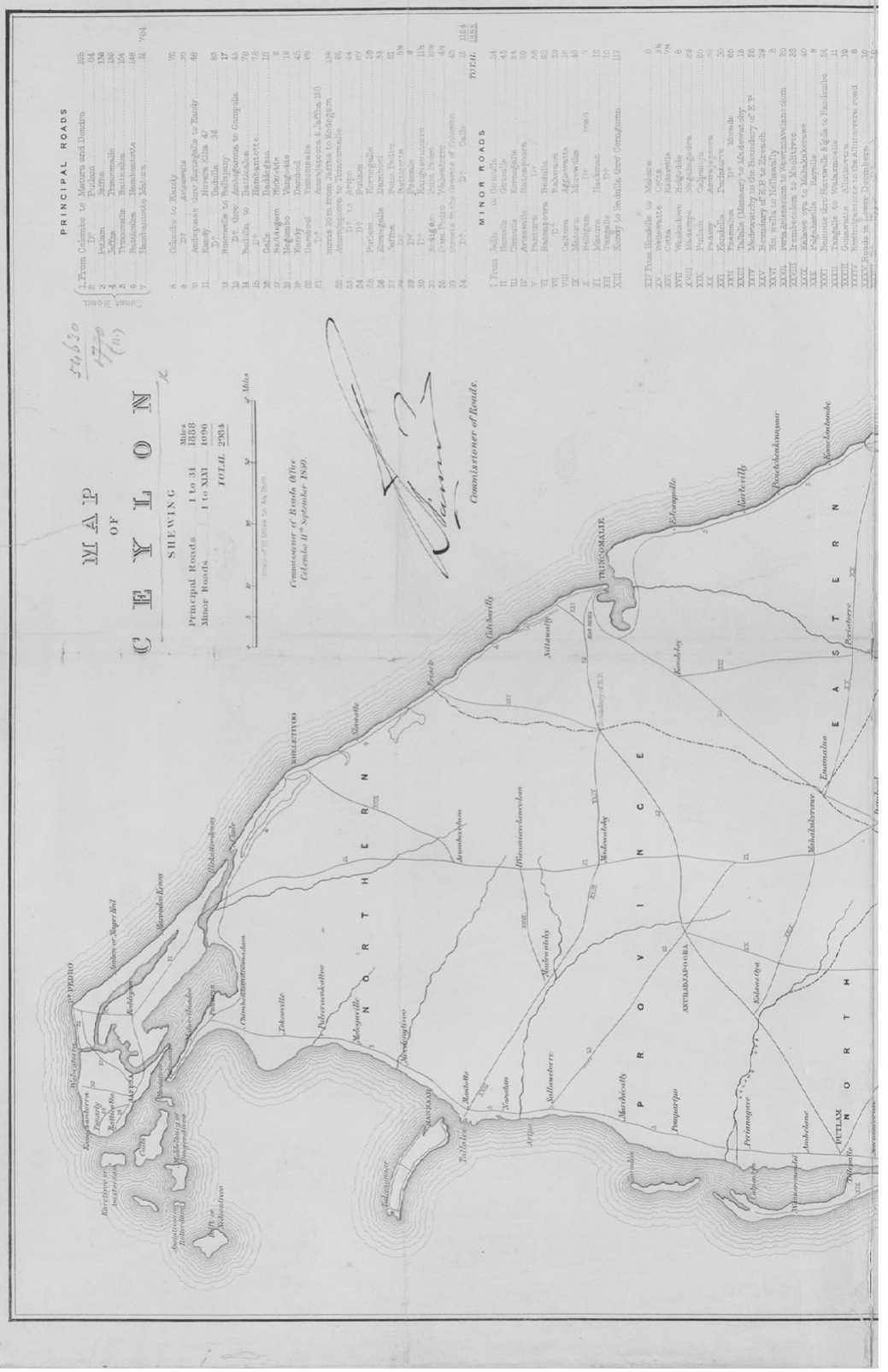

\section{CAMBRIDGE JDUNALS}




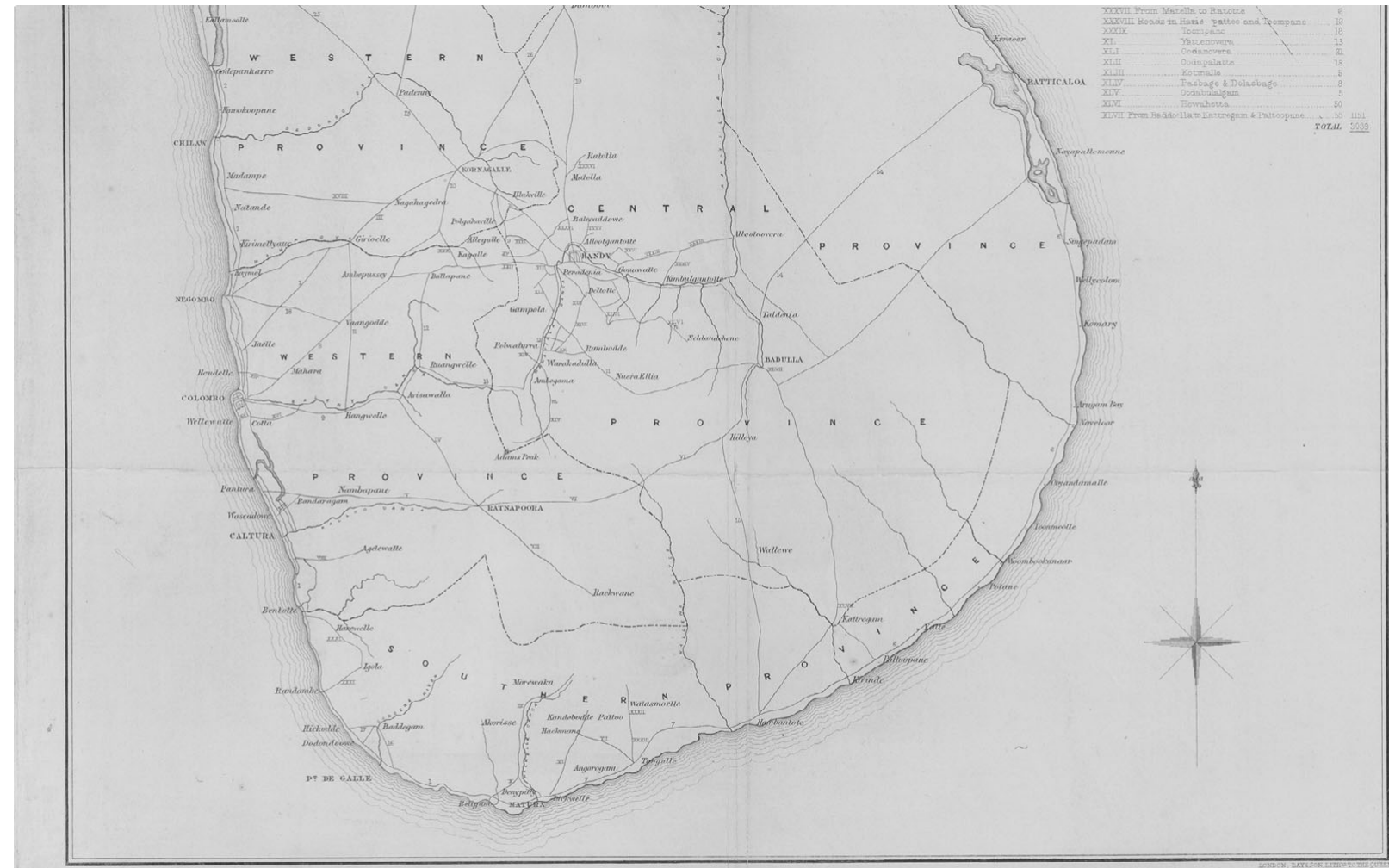

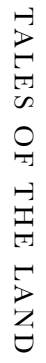

Figure 1. Map of Ceylon showing principal and minor roads (1850?), signed T. Skinner, Commissioner of Roads. 
that now "his lofty monumental column gleamed on the summit of the Kadeganawe pass". ${ }^{91}$ This monument on the side of the road to Kandy became a regular stopping point for travellers, who could climb it and then behold a view quite like that which would greet their eyes atop a mountain. It commemorated Dawson's "science and skill" which had "planned and executed this Road and other works of Public Utility". ${ }^{92}$ The remembrance of a road-builder who had died under the strains of the task, with a column that shot high above the land that was to be tamed, symbolises the anxiety displayed by Britons to acquire the requisite knowledge to govern Ceylon. Ironically, even British delight at their ability to use a local myth to present the powers of their science was short-lived. By the time Charles Pridham wrote his work in 1849 , the tunnel had collapsed, and the Kandy road wound round a hill, adding a further distance of two miles to the journey. ${ }^{93}$

Britons therefore failed in the ideological task they set themselves: the challenges of a tropical climate continued to be insurmountable. Despite this failure, they remained keen on using the road to improve their financial standing in the colony. By 1822, the Deputy Secretary of Government could write how the improvement in communication brought about by roads had increased the consumption of British goods such as cottons, iron, steel, cutlery, earthenware, glassware, haberdashery, umbrellas and bottles; transport costs were said to have been reduced by eighty percent. ${ }^{94}$ Barnes wrote in 1827 that, "the number of carts in Colombo has doubled since the carriage road to Kandy was opened and is daily increasing ..."95 When there was a severe shortage of grain in Kandy in 1824 , as a result of a drought, Barnes noted that he would have been unable to make supplies available without the road. Barnes' economic logic was to use tolls on public works such as roads and bridges, so as to recoup the money expended in their construction. By 1828 , the law had been extended so that Barnes had the right to put in place tolls on roads, canals and ferries, wherever he thought appropriate.

${ }^{91}$ Forbes, Eleven years, Vol. 2, p. 193.

${ }^{92}$ P. M. Bingham, History of the public works department, (Colombo, 1921-3), Vol. 1, p. 13 .

${ }_{93}$ Pridham, An historical, Vol. 2, p. 668.

${ }^{94}$ Beaufort Shexham to Chief Secretary, dated 22 Nov. 1822 , CO 54/82, National Archives, Kew. For transport costs see the short paragraph on the Kandy road in Justin Webb, Tropical Pioneers, p. 28.

${ }^{95}$ Despatch from Edward Barnes, dated April 27 1827, CO 54/97, National Archives, Kew. 
Because British presence in Ceylon was cast as a military form of government, the civil and military affairs of the colony were intimately linked, so that the making of roads, their repair, and the transfer of the land over which they passed, were all encompassed under direct orders served up by the Governor. When Bathurst asked Barnes to separate civil and military concerns, Barnes protested: "here in most instances artificers, labourers and materials can only be procured through the medium of the civil authority, and in many instances the Collectors of Districts must actually cause the work to be performed..." Defending the utility of military orders in the construction of roads and other public works, Barnes wrote that local labourers "cheerfully obey such orders, they assure themselves of the protection of Government, not only for themselves whilst employed in its service but for their families in the event of their dying whilst so employed". 96

By the end of the 1820 , there was agitation for reform of this militarised control. Peter Gordon, who described himself as a renter of farms in India, and of a liberal temperament, published a letter on the political condition of Ceylon, in a volume of documents critiquing British presence on the subcontinent. He wrote that "the MILITARY establishment with which Ceylon is charged is permanent, expensive, and composed of foreign mercenaries ... their task is to destroy her political existence. She is therefore a conquered slave, and all her institutions are dependant on the will of the conqueror". ${ }^{97}$ Gordon noted how public service was legalised, and that the law was merely the whim of the Governor; property was said to be insecure against the crown. Writing of the system of compulsory labour imposed on tenants of land, Gordon wrote that it was arbitrary and undefined. "... in the Candian provinces, from ten years of age the men may be three months of the year in requisition, working under the white taskmaster's lash ... The chief object to which this tax is applied, is, the making a grand military road from Colombo to Candy, a distance of 72 miles, which has employed 800 pressed men eleven years, besides three hundred miserables dressed as pioneers ..."98

${ }^{96}$ Despatch from Edward Barnes, dated July 25 1825, CO 54/101, National Archives, Kew.

97 'Letter to the Editor of the Madras Courier dated 27 November 1827 ' reprinted in Peter Gordon, India or notes on the administration of the establishments in India (Calcutta, 1828 ) p. 59; Edward Barnes' comments on this letter appear in Private letter from Barnes to Secretary of State, dated 22 Jan 1831 , CO 54/1 1 2, National Archives, Kew. ${ }^{98}$ Ibid., p. 63 . 
This debate over the coerciveness of British presence in Ceylon was also discussed in the British parliament in 1830. Mr. Stewart, M. P. for Beverley, proposed a motion for the appointment of a select committee to inquire into the financial state of Ceylon, which was said to stand at $491542 l$, with an excess of expenditure over income each year above $97000 l$. Stewart noted how the Kandyan people were compelled to keep the "military roads" to the interior in repair. This system of enforced labour was said to deter investment given that it operated on a monopoly. "Until a more independent administration of justice is adopted, and a more enlightened commercial policy pursued, Europeans will not be inclined to settle in this fine colony". ${ }^{99}$ Stewart also objected to how "military men" were appointed Governors of Ceylon; "their education and previous habits unfit them to discharge the duties of Governor, with advantage to the public service". 100

While the construction of roads was undertaken to prove the utility and power of British surveying, it speaks therefore at least in part of failure, both in financial terms and in the ideological expression of power.

\section{Labourers and Resistance}

In order to recover how the local inhabitants responded to the Kandy road, it is useful to pay attention to how the system of compulsory labour worked, and how it incorporated allegedly ancient laws. The requirement of compulsory labour was abolished in 1831 , and the military and civil concerns of the British government were divorced in 1833. After these changes, the management of land was predicated on primarily commercial factors, and the rights of local peoples were observed, at least in a limited measure. Yet the use of the Pioneer Corps for military activities continued, and local peoples reacted sometimes violently to the project of constructing roads.

Barnes had two sources of labour available to him in building roads. Firstly, the reorganised Pioneer Corps consisted of six divisions, each in charge of a subaltern with a commanding officer; these consisted in part of labourers brought to Ceylon from Africa and India. ${ }^{101}$ In addition to this, tenants of crown land were expected to work

\footnotetext{
${ }^{99}$ Mirror of Parliament, 1830 , Vol. 2, p. 2016.

${ }^{100}$ Ibid., p. 2014.

101 Bingham, History of the public works department, Vol. 1, p. 193.
} 
gratuitously. Interestingly, the king of Kandy's forces who had so successfully used geography as a means of defence were composed of these same tenants of the land. ${ }^{102}$ Major Skinner, for example, describes how he built roads with the help of "raw untaught Kandians", who were relieved of their labour after two weeks in accordance with the law, thus necessitating the regular training of new men in the requirements of road-making. ${ }^{103}$ This scheme of rajakariya, or duty, was abolished under the recommendations of Commissioners sent to Geylon by the Colonial Office.

The conditions under which local people laboured on the roads may easily be described as miserable. For example, Mrs. Heber writes of how they passed a whole village depopulated by fever. The British engineer who accompanied them explained how he had "built it for the accommodation of a gang of workmen who were employed in erecting a bridge; and on his return, after a very short absence, found it a desert ..."104 J. W. Bennett, in the meanwhile, asked why the Government meted no compensation to the families of those who died while constructing roads. ${ }^{105}$ Lieutenant De Butts wrote of how Kandyans were "dragged from their homes to toil in a service for which they received no sort of remuneration, the wretched Cingalese in many instances failed, from actual inanition and died at the feet of their Christian task-masters. .."106 In response to criticism, Barnes noted that Britain itself had possessed a similar law and that "in the early stages of civilization of all countries there must be calls upon the people for personal service". ${ }^{107}$

In fact, Britons consolidated ancient laws by using them. Mr. M. G. Colebrooke, one of the Commissioners who recommended the negation of this law, noted that the employment of headmen to oversee the system of labour had "tended to foster the prejudices of caste, and to favour abuses of authority". ${ }^{108}$ The old system could only be changed, Colebrooke urged, if advantages were held to headmen, with respect either to the prospect of advancement in the public

102 Skinner, Fifty years in Ceylon, p. 215.

103 Ibid., pp. 29-30.

${ }^{104}$ Heber, A narrative, p. 255.

$105 \mathrm{~J}$. W. Bennett, Ceylon and its capabilities (London, 1843), p. 173.

106 De Butts, Rambles in Ceylon, p. 262.

107 Barnes comments with respect to Commissioners' Report, dated Sept. 101830 , $\mathrm{CO} / 54 / 112$, National Archives, Kew.

108 Report of Mr. M. G. Colebrooke, dated 12 Jan. 1831 , CO 54/112, National Archives, Kew. 
service, or the possibility of becoming independently established in agriculture or commerce. ${ }^{109}$ The manner in which Barnes shored up the role of the headmen in the course of constructing public works is clear, for instance, from the example of the Kirime canal. Barnes is said in this instance to have given honorary titles and gold medals to "deserving headmen" to publicly approve their conduct and services. ${ }^{110}$ Upon the abolition of compulsory labour, rural communities had to be reorganised. For instance, the Collector for Tangalle reported in 1832 that nothing had been done there about "clearing channels, repairing tanks, and improving every natural facility for securing water as well as for guarding against the ruinous effects of inundation". There was now, he reported, a lack of interest in the public good amongst all the Sinhalese. The Collector recommended therefore that a Municipal Committee be formed, so that the Government and the inhabitants of Tangalle could work jointly on public works. ${ }^{111}$

The decades following the abolition of compulsory labour in $183^{1}$ saw the influx of a greater number of European settlers, who brought with them private capital to be deployed in cultivation. Amongst the British, commercial interests rather than military control started to dictate the construction of roads. By this time, the Ceylonese also began to assert their ownership of the land more forcefully. Debates ensued therefore over the question of who had the right to define the entitlement to land. In 1841, Messrs A and R Crowe applied to the Government for assistance in making a road from their estate at Allagalla to the Kandy road. The capitalists declared that they were willing to bear the entire cost of the road, and asked the Government to investigate the ownership of the land and instruct the Agent of Kandy to order the local headmen to allow the road to be carried through. ${ }^{12}$ But one of the local landlords, in the Amarapura korale, instituted a case in court to prevent the road being built on his land. The Government had to acquiesce in the end to his demands. ${ }^{113}$ This case suggests that Sri Lankans were able to exercise more resistance to public works in

${ }^{109}$ Ibid.

${ }^{110}$ Pridham, A historical, Vol. 2., p. 594.

111 Letter from the Collector of Tangalle to the Colonial Secretary, dated Jun 1832, Lot 10/197, Sri Lanka National Archives, Colombo.

${ }^{112}$ A \& R Crowe to the Colonial Secretary, dated 31 Aug. 1841, Lot 10/67, Sri Lanka National Archives, Colombo.

${ }^{113}$ See, J. Baybrooke, Surveyor to A \& R Crower, dated 31 Jan. 1 842, and Colonial Secretary to Crowe \& co. dated 23 Nov. 1842. Lot 10/67, Sri Lanka National Archives, Colombo. 
the later period, once compulsory labour had been abolished, when the land was no longer encompassed under a military style of governance, and when commercial interests came to the fore. Yet some aspects of militarism continued to characterise the construction of roads, tanks and public utilities. For instance, the Pioneer Forces retained a system of ranks and divisions even after 1833 , when they ceased to function under the Military Department. ${ }^{114}$ During the political disturbances of 1848 , for example, the Pioneers were armed and drilled in order to contain indigenous resistance to British rule. ${ }^{115}$

Behind the project of building roads, there always lay the agenda of the introduction of British culture and the suppression of indigenous resistance to colonial rule. Therefore, in 1832, Governor Horton noted his relief that a road was being built from the sea-coast to Anuradhapura, the district where a Pretender to the Kandyan Crown had resided, until his capture in 1830 . Horton noted that a partial insurrection had taken place in this province in 1823 , and that without a road it had been difficult to access and so "almost beyond the controul of the authorities in the interior". ${ }^{116}$ But in a paper given to the Royal Asiatic Society of Ceylon in 1858 , the author documents how the inhabitants of this same district reacted to the construction of roads: “...we have even now to take the greatest care not to bring roads too near villages, as in this case the people invariably abandon their dwellings, and migrate to some neighbouring but more secluded spot". ${ }^{117}$ There are hints elsewhere too that the Ceylonese were aware of the political leverage that roads gave to the British, even in the early period. There were some hushed reports, for instance, about how local peoples had attacked the Pioneer Corps. In 1823, during the period of tense control following the British taking of Kandy, Bathurst was told that six Pioneers had been attacked by a party of Kandyans five miles from Kandy; one of these Kandyans was said to have been armed with a musket, which he fired at the Pioneers, "the

${ }^{114}$ See Bingham, History, Vol. 1, p. 182; for the military drills which characterised the Pioneers see Vol. 2, p. 203.

115 Skinner, Fifty years, p. 262.

${ }^{116}$ Despatch from R. W. Horton, dated 22 Sep. 1832, CO 54/118, National Archives, Kew.

117 A. Oswald Brodie, 'Topographical and Statistical Account of the District of Noowerakalawiya' in Journal of the Ceylon Branch of the Royal Asiatic Society, No.9, (1856-8), p. $15^{1 .}$ 
ball punctuating the Serjeants coat and grazing his side". ${ }^{118}$ A rumour that this attack resulted from the Pioneers "committing depredations on the inhabitants" was also noted.

The indigenous response to the construction of the Peradeniya Bridge also illustrates the manner in which local peoples were threatened by new public works. Like the Kandy Road, the Peradeniya Bridge was built in part to challenge local knowledge. The Kandyans allegedly held from "their ancient tales and legends" that the bridging of the Mahavali ganga, the great river, that runs from Adam's Peak to the eastern coast, was impossible. When work was commenced in 1826 , "with this persuasion they were in the habit of daily assembling to gaze on the gradual progress of the work, and laugh to scorn the vain and impotent labours of the pale faces ..." 119 That the bridge was perceived as a threat is evident from how a plot was formed to destroy it by fire in the course of the rebellion of $1834 \cdot{ }^{120}$

The position of Sri Lankans with respect to the programme of public improvement initiated by Barnes encompasses subjugation and resistance. Though compulsory labour was abolished in 1831, a military form of control over land and labour continued, while commercial interests came to the fore. However, the building of public works continued to be viewed with suspicion while it necessitated the reorganisation of structures of governance and the economy. The Ceylonese expressed their rights to the land and resisted more overtly by obstructing the course of projects, and attacking those who instituted them.

\section{Ancient Wisdom}

The programme of public works relied heavily on the Survey Department. Surveyors traced the projected course of roads, and mapped the terrain of channels, canals and tanks. Yet even with the advent of this new genre of engagement with the land, there continued to be an exchange of geographical knowledge between the British and indigenous peoples, rather like that which characterised the taking of Kandy. Indeed, the notion that the early period of conquest witnessed a trade in information which became irrelevant as British knowledge

${ }^{118}$ Despatch from James Campbell, dated 5 Mar. 1823, CO 54/84, National Archives, Kew.

${ }^{119}$ De Butts, Rambles in Ceylon, 116.

${ }^{120}$ Pridham, A historical, Vol. 1, p. 210. 
improved must be guarded against. In fact Sri Lankan topographical knowledge continued to be appropriated as the century progressed and roads, canals and tanks were built and renovated. But the knowledge that Britons appropriated from local peoples in this later period was often of a technical kind and so different from that which appeared in the boundary ballads. A simple conception of an encounter between colonial and colonised knowledge will therefore not suffice.

For example, suspension bridges were built by inhabitants of the island in pre-colonial times, as British commentators observed. Over the Daduruoya, there was a bridge composed of cable-rattan. Henry Sirr noted that this structure evinced "the ingenuity and readiness of the natives to avail themselves of those means most easily obtained, and calculated for their purpose". ${ }^{121}$ The bridge was commenced by winding canes around the trunks of two large trees that grew on opposite sides of the banks of the river. The canes were then strung across the breadth of the river, and rattan was placed at a sufficient height to form hand-rails. ${ }^{122}$ Sirr noted, in language reminiscent of British comments on Kandyan modes of war, that it was "perfectly astonishing to see the fearlessness with which women, children, or men carrying heavy burthens, will cross one of these aerial structures". ${ }^{123}$ British descriptions of indigenous modes of roadbuilding also emphasise the simplicity of local engagements with nature. At a period when British road-making was at its height, Henry Marshall wrote that under the Kandyan monarch the roads were "chiefly narrow paths, by which men on foot might pass singly, climbing over the rocks, and penetrating through the thickets in the best way they could". Any wheeled-vehicle or animal of conveyance could not take such a path. ${ }^{124}$

Yet Britons made use of these old roads in planning the course of their own modes of conveyance. Governor Brownigg reported in 1815 , for instance, that it had been the policy of government to navigate the land by using the river that meets the sea near Kalutara, and travelling on its left bank on the way to the interior: "... but it has been found on a survey made by Captain Schneider, the Island Engineer, that there is on the right bank of the River an old road which tho now overgrown

${ }^{121}$ Sirr, Ceylon and the Cingalese, Vol. 1, p. 100.

122 Ibid.

${ }^{123}$ Ibid., p. 101.

${ }^{124}$ Henry Marshall, Ceylon, a general description of the island and its inhabitants (London, 1846 , reprinted Dehiwela, 1982). p. 3 . 
with jungle may be easily cleared and made passable for troops and cattle". Brownigg also observed that Schneider was putting all the old roads of Kandy on paper, with the help of "some country born assistants". ${ }^{125}$ Since the island's civilisation was compared with Greek civilisation, the ancient roads of Ceylon were treated as the relics of a civilization that should be restored under colonial rule. ${ }^{126}$ Just as the road to the interior was overgrown, the road to the ancient capital of Anuradhapura from Mihintale, though now merely a forest track, was allegedly once a carriage road. Pridham noted that in 307 B.C., King Devanampiya Tissa sent his carriage on this road to convey the priest Mihindu to the capital from the mountain of Mihintale. ${ }^{127}$

But the prime example of how Britons relied on local expertise in relation to public works concerns colonial engagements with the ruined water tanks of the north-central provinces. In this region, Britons discovered a series of reservoirs built by ancient kings to make arid land cultivable by the collection and diffusion of water. Pridham noted that there were two types of tanks in Ceylon. One kind was formed by vast mounds and the water was supplied by a channel or channels cut from some adjacent stream, while the other type used two sides of a valley for the purpose of embankment. "When industry was checked in Ceylon by intestine commotion, the tanks were neglected, morasses formed, the jungle rapidly encroached on the cultivated land, the climate became permanently deteriorated, the population diminished, and beasts of prey simultaneously multiplied". ${ }^{128}$ Britons believed that if they renovated these tanks, the agricultural productivity of the region could be multiplied several fold. For instance, Mr. M. G. Colebrooke, one of the Commissioners sent to scrutinise the government of Ceylon, wrote in 1831 that "there can be no question" of the "utility and importance" of the tanks as "a means of securing the inhabitants from the effects of droughts and floods, and of improving largely the agricultural resources of the Island". ${ }^{129}$ By 1830 , with the increasing commercialisation of British presence in Geylon, it was hoped that capitalists could be encouraged

${ }^{125}$ Despatch from the Governor to the Secretary of State to the Colonies, dated 26 Sep. 1815 , Lot 5/8/102, Sri Lanka National Archives, Colombo.

${ }^{126}$ For the ancient path to Kandy see Bingham, History of the public works department, Vol. 1, pp. 1-4.

127 Pridham, A historical, Vol 2., p. 535.

128 Pridham, A historical, Vol.2, p. 549.

${ }^{129}$ Report of Mr. M. G. Colebrooke, dated 12 January 1831 , CO/54/1 1 2, National Archives, Kew. 
to invest in the repair of these tanks, and in the cultivation of the desolate provinces in which they were found. ${ }^{130}$

Captain G. Schneider's early surveys of the tanks of Ceylon in 1806-7, form an important moment in British knowledge about the ancient reservoirs of the island. ${ }^{131}$ Upon the instruction of Governor Thomas Maitland, Schneider was despatched to survey the tanks of the districts of Vanni, Magampattu, Matara and Galle, and also to report on the tank that attracted greatest attention in this period, namely Cattukara or Giants' Tank in Manaar. In each of these cases, Schneider commented on why the various tanks had deteriorated. In the Vanni, he noted how the channels for the distribution of water had been clogged up by rotten tree trunks. He continued that oxen and bullocks were allowed to go over these channels and destroy them; unjust headmen were blamed for exercising arbitrary power while neglecting the upkeep of the tanks. ${ }^{132}$ The alleged slothfulness of the Ceylonese was in prime view in these reports. Britons hoped to encourage the colonised to be industrious and to attend to the upkeep of their ancient tanks. They believed that if this were to happen the island would become a repository of grain once again.

Schneider's reports contain a repeated formula of observations, which link topographical information to finance. Comments on the types of crops that may be grown in particular provinces were followed by the prospective size of such a crop, and the extent of the reservoirs. Here is a typical entry from his report on the tanks of Matara:

To this province belong Belligam Tottemanne having 14 villages and provided with about 444 Ammonams of paddy fields consisting of Ande, Maelpaloe, Devil and Otto fields, a part of the fields are served with the aid of water of Polatto River, another part with water that descends from the Hills, another part has the assistance of the Tanks, and the remaining that of the River. In this province are many gardens planted with cocoanut trees, jack trees and coffy trees, and pepper branches and other useful trees. Many empty grounds are here which can be used for making plantations.... When all the paddy fields situated in this province be properly sown, the share of government may be calculated at about 35 oo Parrahs of paddy per annum. ${ }^{133}$

${ }^{130}$ See for instance, Private letter from the Governor to the Secretary of State to the Colonies, dated 24 Dec. 1833, CO 54/131, National Archives, Kew.

${ }^{131}$ For Schneider's reports see: CO 54/1 26, National Archives, Kew.

132 Ibid. p. 20.

133 Ibid. p. 119. 
The planned programme of improvement encompassed the transportation of peoples, the restructuring of the local economy and the re-establishment of an allegedly ancient state of progress. Yet, the conclusion that Britons sought to radically transform already existent structures is not wholly accurate. In fact British plans for the renovation of ancient reservoirs fitted into an already established pattern of improvement, which pre-dated their arrival. For instance in the Vanni, Schneider found a tank that had been renovated about twenty years before his arrival. Families had then been brought from Kandy and remained in the region for eighteen years as cultivators. But the tank had deteriorated once again, leaving the land desolate. ${ }^{134}$ While it is easy to argue that the British surveys of the ancient tanks constituted the arrival of new knowledge; in fact their improvements must be contextualised in a longer history of engagements with the land.

The most striking instance of this reliance appears in a remarkable exchange recorded between Schneider and "the chiefs and principal inhabitants of the provinces of Mantotte and Nanathan" respecting the Giants' Tank. Driving this conversation is the assumption that local peoples possess information worthy of the colonisers' attention. Yet the inhabitants of this region are presented as ignorant of the arts of surveying and measurement, while eagerly awaiting the liberal improvements of British science. Here are some extracts from the exchange between Schneider and the people:

Whether they do not know from any writings or otherwise when, and by whom, the Tank Cattoocarre and the stone bear or dam in the Moesele river have been made.

We have no writings but we heard from our parents that the tank has been made by Sodien (Giants).

Whether they think that it will be any benefit to bring the Tank Cattoocarre in a compleat state of repair.

It will be a very good work as well for the country as for the inhabitants.

Whether they are of opinion that when the Dam of Cattoocarre be brought to a sufficient height, the same will contain a sufficient quantity of water to irrigate the lands without or round about the Tank Cattoocarre.

This we cannot state with certainty as we do not understand to make an exact calculation thereof but we do think, that the extent of Cattoocarre is

${ }^{134}$ See Schneider reports, $\mathrm{CO}_{54} / 1$ 26, National Archives, Kew, p. 14. 
sufficient to contain the necessary quantity of water to irrigate the canals on the outside of the same.

Whether they do not know from experience, that the water will dry up sooner in the small tanks than in the larger.

We know well from experience that the water will be sooner dried in the small tanks than in the larger tanks.

Whither there are any springs, rivers or watercourses in the great wood beyond Cattoocarre that run into sea from the side of Wirtellivo and others in the Moesely river.

Several springs which can very easy be led on the side of Cattoocarre.

How many marcals of grounds can be ploughed and sowed by one man only.

From 20 to 25 Marcals.

As it is the intention of His Excellency the Governor to promote the agriculture as far as the same be practicable, and to present the inhabitants under the British Government from suffering wants in unprofitable years, His Excellency has been pleased to assist the inhabitants of these provinces with paddy seed and at the same time offers to advance of the expences for the repairing of the said tank Cattoocarre or the other small tank, whether they, in either case are inclined to pay to Government I/ $5^{\text {th }}$ instead of I/ I oth part of the crop, until the expences be reimbursed.

With much pleasure and willingness we will and at the same time we thank for His Excellency's good intention towards us and our agriculture ${ }^{135}$

British attempts to revive the arteries of Sri Lankan agriculture in fact met with limited success at the start. In 1833 , Governor Horton could still lament the dilapidated condition of the tanks; he suggested that a joint stock company be formed to aid their reconstruction. ${ }^{136}$ He noted also that in the early phase of British presence in Ceylon an attempt was indeed made to resurrect a set of tanks in the Vanni. It was said to have "been attended with complete success, though the death of [the Gentleman concerned] and the impossibility of directing the efficient attention of Government to such an object prior to the capture of the Kandyan Provinces led to the tanks being again permitted to fall to ruin". ${ }^{137}$ As in the case of road-making, the envisaged repair of the tanks of Ceylon was planned ambitiously, though its outworking was

135 Ibid. p. 254 ff.

${ }^{136}$ Private letter from the Governor to the Secretary of State to the Colonies, dated 24 Dec. 1833, CO 54/131, National Archives, Kew.

${ }_{137}$ Despatch from R W Horton dated 23 Feb. 1833 to the Secretary of State to the Colonies, CO/54/127, National Archives, Kew. 
less confident. Digging beneath the rhetoric of scientific improvement, it is important to remember that these tanks were originally built by Sri Lankans, and that Britons relied on local knowledge in surveying them and proposing repairs of them. There was therefore an accommodation between British surveying and indigenous knowledge, even towards the middle of the nineteenth century.

\section{Conclusions}

In an ironic expression of circularity, Barnes wrote to Bathurst in 1829 advocating the fortification of the heights of Kandy, in order to secure the town in the event of war. He recommended that thirty or forty thousand pounds might be spent on this undertaking. ${ }^{38}$ This letter serves as a curious reminder at this point of the paper of the rhetoric employed by the kings of Kandy in keeping their kingdom closed from the gaze of foreigners. What, if anything, distinguishes the British use of geographical science and Kandyans deployment of their understanding of the land? Historians and theorists have both explicitly and unintentionally treated indigenous and colonial knowledge as separate genres and spoken of how one came to dominate the other. In the case of British advance in Ceylon in the early nineteenth century it is important to stress the shared strategies and rhetoric that characterised the use of geographical knowledge between coloniser and colonised. Both Britons and Sri Lankans engaged with geography aesthetically, and used their knowledge of the land as an expression of power. Furthermore, while roads may seem at first to be a peculiarly British obsession, the colonisers often charted the paths that had predated them. The similarities between the modes of operation of British and Sri Lankan geographies allowed one genre of knowledge to seem a viable contestant to another, while at the same time facilitating the transfer of knowledge and labour in a process of dialogue, exemplified for instance in the training of local peoples in surveying. What historians once separated as indigenous and colonial knowledge were interweaved in complex ways.

Perhaps the best examples of the competition that characterised these orders of information are the Kandy road and the Peradeniya Bridge. The Kurunagala tunnel was built partly to negate the claim

${ }^{138}$ Despatch from Edward Barnes, dated 11 Mar. 1829, CO 54/104, National Archives, Kew. 
that a hole could not be borne through the mountain; while the Peradeniya Bridge was constructed at least partly out of the attraction of disproving the claim that the Mahavali ganga could not be bridged. These competitions capture something of the ideological statements articulated by structures as common-place as roads and bridges. The British programme counted as an assault on the part of colonial practitioners of science, in combating the superior powers that Kandyans possessed in navigating the land. This is illustrated by the overt and subtle forms of resistance displayed by the Ceylonese-encompassing attacks on Pioneers in the early period and cases instituted in court in the later commercial period. Knowledges competed therefore in the early phases of colonial control, to establish priority and trumpet success and such competitions were orchestrated consciously by coloniser and colonised alike. In deploying the idea of competition, I have attempted to come to a more robust view of indigenous practice and a far less optimistic view of colonial science's achievements. However, the notion of competition should not lead to the distancing of separate genres of knowledge because dialogue remained possible. For example, in 1802 , the British Governor sent the Secretary of State a translation of a "mythological and geographical poem", written in the thirteenth century, which he claimed was the first document translated from Sinhalese to English. ${ }^{139}$

Moving our attention from Sri Lanka to India, it appears that the history of road-building on the mainland lagged behind the island by at least a decade. In some ways the equivalent of Barnes in India was Lord William Bentick, the Governor General of Bengal from 1824 to 1834 , who took the first steps to build the Grand Trunk Road from Calcutta to Delhi. ${ }^{140}$ But in fact, as David Ludden has documented, road-building only got under way in the 184 os for the Madras Presidency. ${ }^{141}$ Prior to the British period, there is rich evidence for a network of roads across the subcontinent that were for the greater part surface tracks, which were built-up close to centres of

${ }^{139}$ Despatch from the Governor to the Secretary of State to the Colonies, dated 24 Nov. 1802 , Lot 5/2/69, Sri Lanka National Archives, Colombo.

${ }_{140}$ For a description of the building of the Grand Trunk Road, and other roadwork in India in the early colonial period see, E. W. C. Sandes, The military engineer in India (Chatham, 1935), Vol. 2, Chapters 4-5.

${ }^{141}$ David Ludden, Peasant history in South India (New Jersey, 1985), p. 135. For roads in the Madras Presidency see also, C. Ramachandran, 'East India Company and Communications Development in Madras Presidency' in Journal of Indian History, Vol. $5^{6,}(1978)$ pp. $495^{-5} 5^{1}$. 
pilgrimage and in the proximity of metropolises. The management of these roads was handled by villagers. ${ }^{142}$ Like Sri Lanka, India then had well-established modes of travel and communication prior to colonisation; however, the British mapping of these routes, and the colonial construction of roads, occurred later. This difference may be put down to different administrative traditions. John Rogers has pointed out that the difference between company rule and crown rule is important in coming to an understanding of the contrast between Sri Lankan history and Indian history. ${ }^{143}$ Historiographically, road-making in India has been overshadowed by the attention paid by historians to railways and telegraphs. Scholars such as Gyan Prakash, contrast the scope and rhetoric of European technologies with indigenous modes of travel. ${ }^{144}$ But the subject of roads is possibly a better venue to ground an analysis of what counted as distinct about European technologies, given that a ready comparison with pre-colonial travel is possible.

Within the discipline of the history of science, the influence of the work of Bruno Latour has led to an emphasis on studies of how knowledge is institutionalised in centres of authority such as intellectual societies, museums and collections. ${ }^{145}$ Traditionally, the history of science and empire has stressed the move from hybrid and varied traditions of knowledge to institutionalised and standard science by the later nineteenth century. This is exemplified for instance in the most recent collection of essays on science in the colonial context published under the editorship of Roy Macleod in history of science's research journal, Osiris. ${ }^{146}$ But the story of the increasing institutionalisation of science should not present contestant forms of knowledge which were amateur, military or indigenous as

${ }^{142}$ Jean Deloche, Transport and communications in India prior to steam locomotion (New Delhi, 1993), translated from the French by James Walker.

${ }^{143}$ John D. Rogers, 'Post-orientalism and the Interpretation of Modern Political Identities: The Case of Sri Lanka' in Journal of Asian Studies, Vol. 53, (1994) pp. 10-23.

${ }^{144}$ Gyan Prakash, Another reason: Science and the imagination of modern India (Princeton, 1999). For the telegraph see, Deep Kanta Lahiri Choudhury, "Beyond the reach of monkeys and men": O'Shaughnessy and the telegraph in India, c. 1836-1856' in Indian economic and social history review, Vol. 37 (2000), 331-359. See also the older, Daniel Headrick, The tentacles of progress: Technology transfer in the age of imperialism (New York, 1988).

${ }_{145}$ Bruno Latour, Science in action: How to follow scientists and engineers through society (Milton Keynes, 1987).

${ }^{146}$ Roy Macleod ed. Nature and empire: Science and the colonial enterprise, Osiris, Vol. 15 (2000). 
losing contenders. The boundary ballads that were cited in this paper were still in use in the later nineteenth century. Similarly, surveying should not be identified as science to the exclusion of descriptions of the land in popular travel journals. On the one hand, surveying was closely wedded to commercialism by the mid-century; on the other, similar tropes were employed across travelogues and surveyors' diaries. In effect, a linear progression from amateur to professional and oral networks to institutionalised knowledge simplifies too greatly. There were diverse traditions of knowledge that continued to exist side-by-side with elite technical information. Both the field knowledge employed by colonial engineers and surveyors for the infrastructural development of Ceylon and the traditions of geography entertained by village elders count as two such strands of less rigid knowledge.

The historiography of knowledge and empire has come to an impasse. ${ }^{147}$ Historians need to distinguish between different genres of science, medicine and technology and trace how each of these relate to each other. We need to take account of oral cultures as much as printed publications; we need to recover the knowledge of military practitioners and missionaries who engaged in science. There must be room for secular and religious; amateur and professional and elite and popular knowledges. If we attend to the multiplicity of knowledges that were linked with colonial endeavour, it will be possible to come a more balanced view of how knowledge is implicated in imperialism. It is also necessary to place the colonial trade in knowledge in a longer history of exchange between indigenous and foreign orders of information. All of these avenues of research will reveal the importance of guarding against simple equations between knowledge and colonial power. As more orders of information come to view, it will become possible to describe how these knowledges could contest each other in some situations, while feeding off each other in others.

${ }^{147}$ For a good account of the current state of the field see, Mark Harrison, 'Science and the British Empire' in Isis, Vol. 96 (2005), pp. 56-63. 